\title{
BOGDAN GIEMZA \\ Życie konsekrowane znakiem kościelnej komunii. Uwagi do programu duszpasterskiego Kościoła w Polsce na lata 2010-2013
}

Programy duszpasterskie są - przynajmniej w zamiarach autorów - istotnym narzędziem duszpasterstwa Kościoła w Polsce. Program przygotowany przez Komisję Duszpasterstwa Konferencji Episkopatu Polski na lata 2010-2013 jest realizowany pod hasłem „Kościół domem i szkołą komunii”. W niniejszych rozważaniach, ujętych w trzech punktach, wskazuje się najpierw na główne założenia aktualnego programu ze wskazaniem braku odniesienia do życia konsekrowanego. Następnie zostanie podkreślona rola życia konsekrowanego w życiu Kościoła, ze szczególnym uwzględnieniem eklezjologii komunii, wreszcie w trzeciej części omówione zostaną formy współpracy osób konsekrowanych, zwłaszcza w ramach diecezji.

\section{Program duszpasterski na lata 2010-2013 i niektóre jego braki}

Mówiąc o programach duszpasterskich Kościoła w Polsce trzeba zauważyć, że praktyka ich opracowywania sięga lat pięćdziesiątych XX wieku. Pierwszym całościowym programem była Wielka Nowenna, dzięki której podjęto przygotowanie i odnowę religijno-moralną przed tysiącleciem Chrztu Polski (1957-1966). Głównym architektem programu był ks. kard. Stefan Wyszyński, Prymas Polski ${ }^{1}$.

Bogdan G I E M Z A SDS, ks. dr, adiunkt przy Katedrze Teologii Pastoralnej PWT we Wrocławiu, przełożony Polskiej Prowincji Salwatorianów w latach 1997-2003, redaktor „Studia Salvatoriana Polonica”, e-mail: bogdan@sds.pl

${ }^{1}$ Szerzej na temat założeń i zasad opracowywania programów duszpasterskich zob.: B. G i e m z a: Wobec programu duszpasterskiego na rok 2011/2012. „Homo Dei”. R. 80: 2011 nr 4 s. $11-24$. 
Przygotowany przez Komisję Duszpasterstwa Konferencji Episkopatu Polski program na lata 2010-2013 trzeba widzieć w kontekście minionych doświadczeń pastoralnych i aktualnych wyzwań dla duszpasterstwa Kościoła w naszej Ojczyźnie. Realizacja obecnego programu pod hasłem „Kościół domem i szkołą komunii” jest przewidziana w ciągu trzech lat według następujących założeń hasłowych: 2010/2011 - „W komunii z Bogiem”, 2011/2012 - „Kościół naszym domem”, 2012/2013 - „Być solą ziemi”.

Jak zaznacza we wprowadzeniu do pierwszego roku programu przewodniczący Komisji Duszpasterstwa KEP, ks. abp Stanisław Gądecki, celami ogólnymi tego trzyletniego programu będzie: odkrywanie i pogłębienie duchowości komunii, odnowa $i$ wzmocnienie struktur komunijnych Kościoła oraz krzewienie duchowości komunii. Program duszpasterski pragnie bronić atakowanej przez różne środowiska i zagrożonej $w$ swoim istnieniu rodziny. Realizując trzyletni Program, pragniemy także zaprosić różne środowiska (nie tylko kościelne) do rozmowy i dziatania na rzecz troski o prawdziwe oblicze niedzieli. Pragniemy, by rozważenie tematu »Kościót domem i szkoła komunii« wiązało się z ogólnopolskimi wydarzeniami, takimi jak Krajowy Kongres Diecezjalnych Rad Duszpasterskich (2011/2012) oraz Krajowy Kongres Parafialnych Rad Duszpasterskich $(2012 / 2013)^{2}$.

Hasło programu nawiązuje bezpośrednio do słów Jana Pawła II z listu apostolskiego Novo millennio ineunte, w którym papież nakreślił główne zadania dla Kościoła w trzecim tysiącleciu. Czynić Kościót domem i szkoła komunii - to zdaniem papieża - wielkie zadanie, jakie czeka nas $w$ rozpoczynajacym sie tysiacleciu, jeśli chcemy pozostać wierni Bożemu zamystowi, a jednocześnie odpowiedzieć na najgłębsze oczekiwania świata (NMI 43) ${ }^{3}$. Eklezjologia komunii (communio) została szczególnie rozwinięta podczas obrad Soboru Watykańskiego II i jest kontynuowana w nauczaniu posoborowym Kościoła.

Przyjęcie programu duszpasterskiego jest ważnym krokiem w całościowej strategii działań Kościoła. Niemniej istotną sprawą jest świadomość uwarunkowań, kondycji Kościoła, w jakich przychodzi nam go realizować. Chyba nie przypadkiem sam Jan Paweł II przestrzegał przed pokusą rzucenia się w wir działania i praktycznych inicjatyw. Zanim przystapimy do programowania konkretnych przedsięwzięć - pisał papież - należy krzewić duchowość komunii, podkreślając jej znaczenie jako zasady wychowawczej wszędzie tam, gdzie ksztattuje się

\footnotetext{
${ }^{2}$ S. G ą d e c k i: Stowo wstępne. W: Komisja Duszpasterstwa Konferencji Episkopatu Polski: Rok 2010/2011. W komunii z Bogiem. Kościót domem i szkoła komunii. Program duszpasterski na lata 2010-2013. Red. S. S t u 1 k o w s k i. Poznań 2010 s. 9-10.

3 J a n Pawe 1 I I: List apostolski Novo millennio ineunte. Libreria Editrice Vaticana 2001[cyt. dalej: NMI].
} 
człowiek i chrześcijanin, gdzie formuja się szafarze ottarza, duszpasterze i osoby konsekrowane, gdzie powstaja rodziny i wspólnoty (NMI 43) ${ }^{4}$.

W relacjach prasowych ze spotkań różnych gremiów, których celem było wypracowanie szczegółów programu, często podkreślano, że jego istotą jest zatrzymanie się na sprawie struktur komunijnych w Kościele, szczególnie na poziomie diecezji i parafii. Te zamierzenia są również zawarte w programach wydanych w formie książkowej na lata 2010/2011 i 2011/20125 .

Eklezjologia komunii oprócz wymiaru refleksji teologicznej ma także swój wymiar praktyczny. Jak podkreślał Jan Paweł II, komunia powinna być wyraźnie widoczna $w$ relacjach między biskupami, kaptanami i diakonami, między duszpasterzami a catym Ludem Bożym, między duchowieństwem i zakonnikami, między stowarzyszeniami i ruchami kościelnymi (NMI 45). Realizacji tego postulatu może się dokonać według papieża przez lepsze wykorzystanie struktur duszpasterskich przewidzianych przez prawo kanoniczne, jak rady kapłańskie czy rady duszpasterskie (por. tamże). Jest zatem konieczne - pisał papież - aby Kościót trzeciego tysiaclecia pobudzat wszystkich ochrzczonych $i$ bierzmowanych do uświadomienia sobie obowiązku czynnego udziału w życiu kościelnym (NMI 46).

Jaki jest stan realizacji struktur komunijnych w Polsce, wychowujących i rodzących do odpowiedzialności za Kościół w naszej Ojczyźnie? Trudno jednoznacznie odpowiedzieć, bo nie ma prowadzonych całościowych badań w tym względzie, a sprawozdania dotyczące np. diecezjalnych i parafialnych rad duszpasterskich są często fikcją. Wiele zależy w tym względzie od biskupów i są diecezje, w których te rady dobrze funkcjonują. Ale nie brak też takich obszarów w Polsce, gdzie parafialne rady duszpasterskie istnieją na papierze i zwoływane są jedynie przy okazji wizytacji kanonicznej przez biskupa. Stosownie do wytycznych, gremia te mają charakter doradczy, a nie decyzyjny. Mimo tego pozostaje pytaniem, na ile ich głos jest brany pod uwagę w budowaniu komunii Kościoła, począwszy od płaszczyzny parafialnej przez dekanalną i diecezjalną aż do struktur ogólnopolskich. Czy obecny program duszpasterski wpłynie na zmianę takiego stanu rzeczy, okaże się w najbliższej przyszłości.

Nie podejmując się całościowej oceny aktualnego programu, chciałbym zwrócić uwagę na wyraźny brak odniesienia do życia konsekrowanego. Skoro

\footnotetext{
${ }^{4}$ Niektóre uwagi na temat aktualnych zagrożeń Kościoła w Polsce i realizacji programu duszpasterskiego można znaleźć w: B. G i e m z a: Pokusy wobec komunii Kościoła, „Życie Konsekrowane". R. 2011nr 2(88) s. 40-61.

${ }^{5}$ Zob. Komisja Duszpasterstwa Konferencji Episkopatu Polski: Rok 2010/2011. W komunii z Bogiem. Kościót domem i szkoła komunii. Program duszpasterski na lata 2010-2013. Red. S. Stułkowski. Poznań 2010; Komisja Duszpasterstwa Konferencji Episkopatu Polski: Rok 2011/2012. Kościót naszym domem. Kościót domem i szkoła komunii. Program duszpasterski na lata 2010-2013. Red. S. S t u ł k o w s k i. Poznań 2011.
} 
mowa o tworzeniu i rozwijaniu struktur komunijnych w Kościele, to życie konsekrowane ma niewątpliwie nie tylko zasługi w tym względzie, ale też bogate doświadczenie zarówno w wymiarze praktycznym, jak i refleksji teologicznej, o czym w dalszej części rozważań. W przedkładanych materiałach programowych zostało to zupełnie pominięte. Zwracam uwagę na ten brak nie tylko dlatego, że jestem zakonnikiem, ale ponieważ taka sytuacja powtarza się nie po raz pierwszy. Gdy w latach dziewięćdziesiątych XX w. opracowywany był na nowo program studiów dla wyższych seminariów duchownych w Polsce, osobiście interweniowałem, by w ramach wykładów i ćwiczeń z teologii pastoralnej uwzględniono problematykę apostolskiego wymiaru życia konsekrowanego. Trudno się oprzeć wrażeniu, że mimo kolejnych dokumentów i wzniosłych słów pod adresem życia konsekrowanego, bywa ono niekiedy traktowane po macoszemu.

\section{II. Życie konsekrowane w komunii Kościoła}

Jan Paweł II w adhortacji Vita consecrata stwierdza, że życie konsekrowane nie jest rzeczywistościq odosobniona i drugorzędna, ale sprawa całego Kościoła. [...] Znajduje się [ono] w samym sercu Kościoła jako element o decydującym znaczeniu dla jego misji (VC 3) ${ }^{6}$. Znajduje się w samym sercu Kościoła, ponieważ wyraża najgłębszą istotę powołania chrześcijańskiego: jest radykalnym darem z siebie złożonym Bogu. Natura eklezjalna życia konsekrowanego jest jego cechą nieodłączną, nie ogranicza się tylko do różnych pól działalności pastoralnej zakonników i zakonnic w Kościele. We wspomnianej adhortacji, Jan Paweł II wyróżnia trzy konstytutywne elementy posłannictwa osób konsekrowanych: 1) konsekrację, 2) życie braterskie / siostrzane we wspólnocie i 3) specyficzną misję instytutu lub wspólnoty (por. VC 72). Zwykle ograniczamy się i zatrzymujemy tylko nad trzecim elementem, konkretnymi dziełami apostolskimi jakie podejmują poszczególne rodziny zakonne. Tymczasem zapominamy o dwóch bardzo istotnych elementach, jakim jest świadectwo konsekracji i świadectwo życia wspólnotowego.

Mając na uwadze perspektywę eklezjologii komunii, zatrzymajmy naszą uwagę na życiu wspólnotowym, jako jednej z istotnych cech życia konsekrowanego. Giordano Cabra w jednym ze swoich rozważań nt. życia braterskiego napisał: Życie braterskie jest tematem, na którym ciaża tu i tam, i to od dawna, mroczne cienie braku złudzeń i sceptycyzmu. Entuzjastycznemu wzrostowi opracowań teologicznych dotyczacych komunii eklezjalnej $i$ życia braterskiego odpowiada nierzadko rozczarowanie z powodu tylko nielicznych udanych realizacji. [...] Przejście od deklaracji do spetnienia, od diagnozy do terapii, od programu

${ }^{6} \mathrm{~J}$ a n P a w e $\nmid$ I I: Posynodalna adhortacja apostolska o życiu konsekrowanym i jego misji w Kościele i w świecie Vita consecrata. W: Życie konsekrowane w dokumentach Kościoła. Kraków $2003^{2}$ s. 579-675 [cyt. dalej: VC]. 
życia do codziennej rzeczywistości jest bardzo trudne, bardziej wymagające, niż to się wydawato. Oznacza to, nie chcac bynajmniej zniechęcać, że życie braterskie to "poważny przypadek«, centralna rzeczywistość chrześcijańska, węzłowy punkt naszej egzystencji jako chrześcijan i osób konsekrowanych ${ }^{7}$. Zmarły kard. Basil Hume (1923-1999) jako relator na Synodzie Biskupów w 1994 r. poświęconym życiu konsekrowanemu, określił osoby zakonne jako budowniczych komunii ${ }^{8}$. Z kolei we wskazaniach dotyczących formacji w instytutach zakonnych stwierdza się, że zakonnicy, jako wspólnota eklezjalna, sa powołani, by być $w$ Kościele $i w$ świecie ekspertami $w$ dziedzinie komunii, świadkami i twórcami tej komunii (nr 25) ${ }^{9}$. Natomiast adhortacja Vita consecrata stwierdza wprost, że od osób konsekrowanych oczekuje się, by byty prawdziwymi mistrzami komunii i by żyty jej duchowościa (VC 46). Pisząc o misji życia konsekrowanego, Jan Paweł II tak stwierdza: Jest jeszcze jeden szczególny $i$ swoisty element życia zakonnego, który sprawia, że ma ono udziat $w$ misji Chrystusa: jest nim życie braterskie we wspólnocie dla misji. Życie zakonne będzie zatem tym bardziej apostolskie, im głębsze będzie jego oddanie się Panu Jezusowi, im bardziej życie wspólnotowe będzie przepojone duchem braterstwa $i$ im gorliwiej zaangażowane $w$ spetnianie szczególnej misji Instytutu (VC 72).

Kiedy czytamy te słowa, to możemy wpaść w euforię i zadufanie albo w przerażenie z racji oczekiwań stawianych wobec życia konsekrowanego. W czym tkwi fenomen życia we wspólnocie zakonnej? Dlaczego zwraca się dziś tak wielką uwagę na jego znaczenie w kontekście życia Kościoła i świata? Co sprawia, że mimo trudności w realizacji życia we wspólnocie, mieni się ono różnorakimi barwami, fascynuje i odpycha, wzbudza podziw, uznanie u jednych, a brak zrozumienia u innych?

Powołanie do życia konsekrowanego jest powołaniem nie tylko do osobistej zażyłości i jedności poszczególnego człowieka z Bogiem, ale jest powołaniem do tworzenia wspólnoty osób, która będzie zjednoczona więzią komunii z Bogiem i $\mathrm{z}$ innymi ludźmi, braćmi lub siostrami w danej rodzinie zakonnej. Tę więź przeżywają także osoby konsekrowane nie żyjące we wspólnotach: Wymiar braterskiej wspólnoty nie jest obcy ani Instytutom świeckim, ani też indywidualnym formom życia konsekrowanego. Pustelnicy pograżeni w swojej samotności, nie tylko nie wyłamuja się z kościelnej komunii, ale stuża jej swoim specyficznym charyzmatem kontemplacyjnym; dziewice konsekrowane, żyjace $w$ świecie, urzeczywistniaja swoja konsekrację przez szczególna więź komunii z Kościołem par5 s. 22.

${ }^{7}$ P. G. Cabra: Profetyczny wymiar życia braterskiego. „Via Consecrata”. R. 4: $2001 \mathrm{nr}$

${ }^{8}$ Zob. Życie konsekrowane i jego misja w Kościele i w świecie. »Relatio ante disceptationem» kard. B. Hume'a. „L'Osservatore Romano”. Wydanie polskie. R. 16: 1995 nr 1 s. 20.

${ }^{9}$ Kongregacja ds. Instytutów Życia Konsekrowanego i Stowarzyszeń Życia Apostolskiego: Wskazania dotyczace formacji w instytutach zakonnych. Warszawa 1990. 
tykularnym i powszechnym. To samo dotyczy konsekrowanych wdów i wdowców (VC 42).

Trzeba jednak ciągle uświadamiać sobie, iż mówiąc o wspólnocie, mówimy o darze udzielanym przez Boga, a nie o „wspólnocie interesów” opartej na ludzkich układach. Podkreśla to mocno dokument Kongregacji Instytutów Życia Konsekrowanego i Stowarzyszeń Życia Apostolskiego pt. Życie braterskie we wspólnocie (1994) ${ }^{10} \mathrm{w}$ rozdziale pierwszym. Czytamy m.in.: Wspólnota zakonna jest nie tylko dziełem ludzkim, lecz przede wszystkim darem Ducha Świętego. Z miłości Bożej rozlanej w sercach przez Ducha wspólnota zakonna bierze bowiem poczatek jako prawdziwa rodzina zgromadzona $w$ imię Pana (ŻBW 8). W innym miejscu dokumentu podkreśla się, że wspólnota zakonna jest przede wszystkim tajemnica, która należy kontemplować i przyjmować (jako dar) z wdzięcznym sercem $i$ w jasnej perspektywie wiary (ŻBW 12). W takiej perspektywie trzeba widzieć nie tylko powołanie osoby konsekrowanej, ale każdego człowieka: Stwarzając istote ludzka na swój obraz i podobieństwo, Bóg stworzyt ja do komunii. Bóg Stwórca, który objawit się jako Miłość, Trójca, Komunia, powotał człowieka do głębokiej więzi z soba i do komunii międzyosobowej, to jest do powszechnego braterstwa. Oto najwznioślejsze powołanie człowieka: zjednoczyć się więzia komunii z Bogiem i z innymi ludźmi, swoimi braćmi (ŻBW 9). Inicjatywa należy zatem najpierw do Boga. Zapewne pozostanie dla nas tajemnicą, jak to się dzieje, że człowiek, istota wolna, może ten dar przyjąć lub go odrzucić, odpowiedzieć na wezwanie lub pominąć je milczeniem. Ujęcie to, jak widać, dalekie jest od moralizatorstwa i woluntaryzmu, w atmosferze których nieraz kształtowało się życie chrześcijańskie i powołanie zakonne. Najpierw trzeba było zachowywać reguły, przykazania, a dopiero z tego wysiłku miało wzrastać życie wspólnotowe. O tym, że to Bóg sam jako pierwszy przejmuje inicjatywę obdarowywania nas swoją Miłością mówiło się mniej. A w każdym razie nie stawiało się tego na pierwszym miejscu.

Zadanie związane $\mathrm{z}$ budowaniem komunii i uwzględnieniem duchowości komunii wynika z Bożego zamysłu wobec Kościoła i życia konsekrowanego. Kościót powierza wspólnotom życia konsekrowanego - czytamy w adhortacji Vita consecrata - szczególna troskę o wzrost duchowości komunii przede wszystkim $w$ tonie kościelnej wspólnoty i poza jej obrębem (VC 51). Kościół bardzo liczy na świadectwo takich wspólnot, najpierw ze względu na zachowanie i umocnienie własnej jedności, zwłaszcza w czasach dzisiejszych, gdy dochodzą do głosu szczególnie silne dążenia odśrodkowe i rozłamowe (por. VC 46). Kluczowym aspektem tej kościelnej komunii jest wierność umystu i serca wobec nauczania Biskupów, która wszystkie osoby konsekrowane powinny lojalnie realizo-

\footnotetext{
${ }^{10}$ Kongregacja ds. Instytutów Życia Konsekrowanego i Stowarzyszeń Życia Apostolskiego: Życie braterskie we wspólnocie. »Congregavit nos in unum Christi amor «. Ząbki 1994 [cyt. dalej: ŻBW].
} 
wać w życiu, dając o niej otwarcie świadectwo wobec Ludu Bożego; dotyczy to zwłaszcza osób zaangażowanych na polu badań teologicznych i nauczania, w dziedzinie wydawnictw, katechezy, środków społecznego przekazu (VC 46).

Podkreślanie znaczenia komunii $\mathrm{w}$ życiu konsekrowanym wynika także $\mathrm{z}$ potrzeb współczesnego świata, tak często podzielonego i rozdartego oraz przemian społecznych, dokonujących się we współczesnym świecie. Wspólnoty zakonne ze względu na swój, często, międzynarodowy charakter stają się wymownym znakiem przekraczania barier kontynentalnych, kulturowych, rasowych, etnicznych. W świecie pełnym konfliktów wspólnoty życia konsekrowanego, $w$ których spotykają się jako bracia i siostry ludzie różnego wieku, języków i kultur, staja się znakiem zawsze możliwego dialogu oraz komunii (VC 51). Trzeba jednakże przyznać, że nie jest to łatwe zadanie do realizacji na co dzień.

Na znaczenie wspólnotowego wymiaru życia konsekrowanego w kontekście migracji i globalizacji wskazał Jan Paweł II w adhortacji o Kościele w Europie ${ }^{11}$. Czytamy w niej: Specyficzny wkład, jakim osoby konsekrowane moga stużyć Ewangelii nadziei, wynika z pewnych charakterystycznych aspektów obecnego oblicza kulturowego i społecznego Europy. [...] W dzisiejszej sytuacji wielości kultur i religii nieodzowne jest świadectwo ewangelicznego braterstwa, które charakteryzuje życie konsekrowane, czynią je bodźcem do oczyszczania i integracji różnych wartości przez przezwyciężanie przeciwieństw (EiE 38). Z kolei o. Timothy Radcliffe OP, były generał dominikanów, podczas kongresu życia konsekrowanego w 2004 r. stwierdzit: W tym kryzysie, zwiazanym z brakiem miejsca zamieszkania, życie zakonne stało się, oczywiście, naglacym wołaniem, aby być znakiem wielkiego zamieszkania w przestronnym domu Boga, szerokiego otwarcia Królestwa Bożego, w którym każdy może czuć się w domu i żyć spokojnie. Jeżeli jesteśmy $w$ domu $w$ przestronności Boga, to możemy czuć się $w$ domu $z$ kimkolwiek. Możemy to realizować na różne sposoby. Tysiace zakonników i zakonnic, braci $i$ sióstr, pozostawiło swoje domy, aby czuć się $w$ domu pomiędzy cudzoziemcami. Mate wspólnoty sióstr powstaja $w$ wioskach muzutmańskich od Maroka aż po Indonezję, uczac się dzielić obcy język, jedzac obce potrawy, wtaczajac się w tkanke innego sposobu bycia ${ }^{12}$.

Kościół bardzo liczy na świadectwo takich wspólnot ze względu na świat, któremu chciałby ukazywać przykłady wspólnot, w których wzajemna troska pomaga przezwyciężyć samotność, więź braterska budzi we wszystkich poczucie współodpowiedzialności, a przebaczenie zabliźnia rany (por. VC 45). Aby ukazać światu swoje prawdziwe oblicze, Kościót pilnie potrzebuje takich wspólnot bralej: $\mathrm{EiE}]$.

${ }^{11}$ J a n Paweł I I: Adhortacja apostolska Ecclesia in Europa. Kraków 2003 [cyt. da-

${ }^{12}$ T. R a d c 1 if f e: Życie zakonne po 11 września. Jakie znaki ofiarujemy? ,Biuletyn Konferencji Wyższych Przełożonych Zakonów Żeńskich”. R. 2005 nr 24 s. 63. 
terskich, które samym swym istnieniem wnosza wkład $w$ nowa ewangelizację, ponieważ w konkretny sposób ukazują owoce nowego przykazania (VC 45).

Wkład doświadczenia życia wspólnotowego w życiu konsekrowanym, trzeba również widzieć w perspektywie tendencji zjednoczeniowych w Europie i w świecie. Kościół utrzymuje, że nie można budować Europy, wspólnoty ogólnoświatowej tylko na handlu, wielkich koncernach czy bankach, z pominięciem solidarności i wartości duchowych. Stąd wysuwany postulat, by przejść od wspólnoty handlowców do wspólnoty solidarności, podtrzymywanej i umacnianej przez poczucie braterstwa. W tej dziedzinie życie konsekrowane posiada długą, prawie dwutysięczną historię. Jest to najdłuższe doświadczenie w realnej historii i efektywnej solidarności, opartej na wartościach Ewangelii i dzięki zakorzenieniu w Chrystusie ${ }^{13}$.

\section{Współpraca podmiotów życia konsekrowanego w Kościele partykularnym}

Nie do pomyślenia jest obecnie koncepcja pracy apostolskiej w izolacji, bez wzajemnych kontaktów i współpracy różnych gremiów na różnych szczeblach, począwszy od płaszczyzny ogólnokościelnej przez narodową, diecezjalną aż do parafialnej włącznie. Nasze uwagi ograniczymy do obecności i współpracy życia konsekrowanego w Kościele partykularnym. Warto w tym kontekście przypomnieć słowa Jana Pawła II wygłoszone w czasie pierwszej audiencji udzielonej Unii Przełożonych Generalnych, w dniu 24 listopada 1978 r.: Gdziekolwiek jesteście na świecie, poprzez Wasze powołanie istniejecie »dla Kościoła powszechnego«, ale przez swoje postannictwo jesteście »w określonym Kościele lokalnym«. Tak więc Wasze powołanie dla Kościoła powszechnego urzeczywistnia się wewnatrz Kościoła lokalnego. Trzeba dotożyć wszystkich starań, ażeby »życie konsekrowane « rozwijato się w poszczególnych Kościołach lokalnych, ażeby przyczyniało się do ich duchowej budowy, ażeby stanowito ich szczególna sitę. Jedność z Kościotem powszechnym poprzez Kościót lokalny jest wasza droga ${ }^{14}$. Osobną kwestią jest problematyka współpracy zakonników ze świeckimi.

Mimo bogatego nauczania Kościoła na temat eklezjalnego i komunijnego wymiaru życia konsekrowanego, rzeczywistość i praktyka wciąż nie nadążają za refleksją teologiczną i pozostawiają wiele do życzenia. Najczęściej występująca mentalność pasterzy i samych osób konsekrowanych optuje za łatwymi, bezpośrednimi i doraźnymi rozwiązaniami. Rzadko są brane pod uwagę zasady wynikające z teologii życia konsekrowanego. Niestety, chodzenie na skróty nie uła-

\footnotetext{
${ }^{13}$ G. C a b r a: Życie zakonne i nowa Europa. „Via Consecrata”. R. 6: 2003 nr 6 s. 19.

${ }^{14} \mathrm{~J}$ a n P a w e $\nmid$ I I: Życie zakonne jako droga do świętości. W: J a n P a w e ł I I: Nauczanie papieskie 1978. Poznań 1987 s. 96.
} 
twia wcielania w życie wzniosłych idei i trzeba przyznać, że współpraca instytutów życia konsekrowanego z biskupami nie jest wolna od niedomówień i problemów. Pomocą we właściwym określeniu tej współpracy jest niewątpliwie dokument pt. Mutuae relatione" z 14 maja 1978 r., wydany przez ówczesną Kongregację Biskupów i Kongregację ds. Zakonników i Instytutów Świeckich ${ }^{15}$, któremu warto się przyjrzeć, odnosząc jego wskazania i sugestie do dzisiejszej sytuacji Kościoła w Polsce. Mimo upływu lat i promulgowania w międzyczasie nowego kodeksu prawa kanonicznego, dokument ten zachowuje swoją aktualność i wciąż oczekuje na pełną realizację. Mówili o tym uczestnicy sympozjum wyższych przełożonych zakonnych, jakie odbyło się w dniach 10-12 października 2006 r. na Jasnej Górze z udziałem ks. kard. Franca Rodé, ówczesnego prefekta Kongregacji Instytutów Życia Konsekrowanego i Stowarzyszeń Życia Apostolskiego ${ }^{16}$.

Wspomniany dokument Mutuae relationes wyróżnia trzy płaszczyzny współpracy biskupów i zakonników: 1) w zakresie formacji, 2) działania i 3) koordynacji (por. MR 23).

W zakresie formacji należy wskazać na potrzebę studium nauki Kościoła odnoszącej się do właściwego rozumienia Kościoła, w tym Kościoła partykularnego, następnie właściwego rozumienia powołania do życia zakonnego i właściwych relacji zachodzących między nimi (por. MR 29). Odpowiednia formacja intelektualna odgrywa znaczącą rolę w kształtowaniu dojrzałości powołania kapłańskiego i zakonnego (por. MR 31).

Wśród pozytywnych inicjatyw trzeba wskazać m.in. dzień życia konsekrowanego obchodzony w Kościele z inicjatywy Jana Pawła II w dniu 2 lutego.

\footnotetext{
${ }^{15}$ Kongregacja Zakonów i Instytutów Świeckich oraz Kongregacja Biskupów: Wytyczne dla wzajemnych stosunków między biskupami i zakonnikami w Kościele »Mutuae relationes«. W: Życie konsekrowane w dokumentach Kościoła. Kraków 2003² s. 157-188 [cyt. dalej MR].

${ }^{16}$ Podczas wspomnianego sympozjum o. K a z i mi e r z L o r e k CRSP wskazał na niektóre problemy, które sygnalizują wyżsi przełożeni (zakonów męskich i żeńskich) w Polsce we współpracy z biskupami i księżmi diecezjalnymi: a) niewystarczającą znajomość ze strony biskupów specyficznych celów instytutów zakonnych i brak dialogu na ten temat; b) brak lub marginalizację zakonników w radach i organach doradczych istniejących w poszczególnych diecezjach; c) braki w formacji kandydatów do kapłaństwa w seminariach diecezjalnych nt. życia konsekrowanego; d) nadmierne oczekiwania biskupów względem osób zakonnych z lekceważeniem fundamentalnych zasad życia zakonnego; e) instrumentalne traktowanie zakonników. Z kolei kard. R o d é zwrócił również uwagę na problemy we współpracy, które są sygnalizowane ze strony biskupów: a) odseparowywanie się zakonników od życia Kościoła lokalnego; b) nie podejmowanie lub porzucanie przez zakonników planów diecezjalnych; c) niedostateczna znajomość ze strony zakonników teologii Kościoła lokalnego; d) brak dialogu z biskupami przy tworzeniu nowych wspólnot zakonnych zob. K.M. L o r e k: Eklezjologia wspólnoty między biskupami $i$ zakonnikami $w » M u t u a e$ relationes«. „Biuletyn Konferencji Wyższych Przełożonych Zakonów Żeńskich”. R. 2006 nr 27 s. 64-73; F. R od é: Osoby konsekrowane w Kościele wedtug dokumentu »Mutuae relationes“. „Biuletyn Konferencji Wyższych Przełożonych Zakonów Żeńskich”. R. 2006 nr 27 s. 52-57.
} 
Zwiastunem pozytywnych zmian jest również Rok Życia Konsekrowanego ogłoszony w metropolii górnośląskiej, który trwa od 2 lutego 2011 do 2 lutego 2012 r. Na rozpoczęcie obchodów roku, biskupi poszczególnych diecezji metropolii (katowickiej, opolskiej i gliwickiej) skierowali do diecezjan listy pasterskie, w których przedstawili racje ogłoszenia takiej inicjatywy. W realizację zamierzeń wpisuje się m.in. sympozjum zorganizowane na Wydziale Teologicznym Uniwersytetu Opolskiego pt. „Kościół naszym domem. Duchowość komunii we wspólnotach życia konsekrowanego" (19 listopada 2011 r.). Wyrazem dobrej współpracy w dziedzinie promocji powołań kapłańskich i zakonnych są nabożeństwa i msze św. organizowane w katedrze wrocławskiej w każdy pierwszy czwartek miesiąca z udziałem wychowawców, alumnów diecezjalnych i zakonnych oraz sióstr juniorystek z terenu archidiecezji wrocławskiej.

Wśród braków należałoby wskazać, że nadal w niewielu seminariach diecezjalnych są prowadzone wykłady z teologii życia konsekrowanego, co skutkuje brakiem zrozumienia dla specyfiki powołań zakonnych, zwłaszcza sióstr zakonnych. Należy w tym miejscu przypomnieć słowa Benedykta XVI skierowane 3 grudnia 2005 r. do drugiej grupy polskich biskupów o współpracy biskupów z zakonami i ich odpowiedzialności za zakony w diecezjach: Bardzo zachęcam Was, Bracia, abyście otoczyli swa troska żeńskie wspólnoty zakonne, jakie znajduja się $w$ Waszych diecezjach. Siostry podejmujace różnorakie posługi w Kościele zastuguja na najwyższy szacunek, a ich praca powinna być uznawana $i$ właściwie doceniona. Nie powinny też być one pozbawione wtaściwej opieki duchowej oraz możliwości intelektualnego rozwoju $i$ wzrastania $w$ wierze $e^{17}$. Wiele również jest do zrobienia w zakresie wspólnych działań na rzecz promocji powołań kapłańskich i zakonnych. Zaprzeczeniem eklezjologii komunii jest sytuacja w pewnych diecezjach polskich, w których czyni się utrudnienia kandydatom mającym zamiar wstąpić do seminarium zakonnego.

Drugi obszar współpracy, czyli płaszczyzna działania jest uwarunkowany potrzebami diecezji oraz charyzmatem poszczególnych rodzin zakonnych. Według kard. B. Hume'a każdy biskup na terenie swojej diecezji, będąc w komunii z papieżem i kolegium, powinien uznać, docenić, chronić, promować, koordynować i rozeznać życie konsekrowane ${ }^{18}$. Dokument Mutuae relationes mówi o instytucji wikariusza biskupiego dla osób zakonnych. Jego zadaniem jest niesienie pomocy biskupowi diecezjalnemu na różnych odcinkach pracy duszpasterskiej w

\footnotetext{
${ }^{17}$ B e n e d y kt X V I: Do biskupów polskich. Przemówienie wygłoszone z okazji wizyty ad limina Apostolorum w roku 2005. Poznań 2005 s. 21.

${ }^{18}$ Życie konsekrowane i jego misja w Kościele $i w$ świecie. »Relatio ante disceptationem《 kard. B. Hume'a, dz. cyt., s. 16.
} 
diecezji. Z tego względu wydaje się pożadane, by w sprawie wyboru kandydata biskup konsultowat się z zakonnikami i zakonnicami (MR 54) ${ }^{19}$.

Takie są wytyczne, a jak wygląda praktyka? W wielu diecezjach brak jest wikariusza biskupiego ds. życia konsekrowanego. Często są to referenci diecezjalni nie bardzo wiedzący czym jest ta forma powołania w Kościele. Podobnie często brakuje konsultacji z osobami konsekrowanymi przy mianowaniu wspomnianego wikariusza.

Gdy chodzi o apostolstwo instytutów życia konsekrowanego, to Kodeks Prawa Kanonicznego wprowadza rozróżnienie na dzieła własne i dzieła powierzane zakonnikom (zob. kan. 677 i 681 ) $^{20}$. Dla zapewnienia stałości w pasterskiej współpracy zaleca się zawieranie odpowiednich pisemnych umów między przełożonymi zakonnymi a biskupem lub innymi kompetentnymi osobami (por. MR $57)^{21}$. Niestety, również realizacja tych wskazań w praktyce pozostawia wiele do życzenia. Pełniąc obowiązki wyższego przełożonego zakonnego przez sześć lat nie zdołałem doprowadzić do podpisania stosownych umów w sprawie parafii w niektórych diecezjach, mimo usilnych zabiegów z mojej strony.

Wreszcie trzecia płaszczyzna współpracy - koordynacji, również nie jest wolna od niedomówień i problemów. Dla ułatwienia dialogu - jak stwierdza adhortacja Vita consecrata - bardzo pożyteczne może być $w$ tej perspektywie tworzenie - tam, gdzie dotąd nie istnieja - oraz ożywianie dziatalności krajowych komisji mieszanych Episkopatu i Wyższych Przełożonych Zakonów Męskich $i$ Żeńskich, które będa rozpatrywaty problemy interesujace obie strony (VC 50). Jeśli chodzi o środki instytucjonalne na rzecz współpracy między biskupami i przełożonymi (rady, konferencje, komisje), dokument Mutuae relationes wyróżnia trzy poziomy: diecezjalny, krajowy i powszechny.

Na szczeblu ogólnopolskim istnieje w ramach Konferencji Episkopatu Polski Komisja Mieszana: Biskupi - Wyżsi Przełożeni Zakonni. Zadaniem tego gremium jest prowadzenie konsultacji, wspólne wypracowywanie propozycje rozwiązań do zastosowania w poszczególnych diecezjach i zakonach uwzględniających specyfikę diecezji oraz zakonów. Na poziomie diecezji, daje się zauważyć brak obecności albo obecność sporadyczną osób zakonnych w różnych

${ }^{19}$ Zob. G. B a r to s ze w s ki: Rola i znaczenie wikariusza biskupiego dla instytutów życia konsekrowanego i stowarzyszeń życia apostolskiego $w$ diecezji. „Biuletyn Konferencji Wyższych Przełożonych Zakonów Męskich w Polsce”. Warszawa X/'97 nr 36 s. 79-90.

${ }^{20}$ Wyjaśnienie tego rozróżnienia znajdziemy m.in. w komentarzu: B. W. Z u b e r t: Komentarz do Kodeksu Prawa Kanonicznego. T. 2 cz. 2. Lublin 1990 s. 186-187.

${ }^{21}$ Zob. P. H. K olv e n b a c h: Relacje między biskupami i przełożonymi generalnymi $w$ kwestiach dotyczacych otwierania i zamykania dziet. „Biuletyn Konferencji Wyższych Przełożonych Zakonów Żeńskich”. R. 1998 nr 7 s. 102-105. 
radach diecezjalnych. W niewielu polskich diecezjach istnieją rady ds. życia konsekrowanego.

Widzimy więc, że sprawa właściwej współpracy osób konsekrowanych z Kościołem partykularnym wymaga wciąż jeszcze wiele poszukiwań dla wzajemnego dobra, ostatecznie dla dobra Kościoła i chwały Boga. 